\title{
LEXICON
}

VOLUME 3
Number 2, October 2014

Page 157-165

\section{EDWARD TULANE'S CHARACTER DEVELOPMENT IN KATE DICAMILLO'S THE MIRACULOUS JOURNEY OF EDWARD TULANE}

\author{
Azaliasari Aqmarina
}

\begin{abstract}
This article examines a novel entitled The Miraculous Journey of Edward Tulane by Kate Dicamillo. It aims to identify the character development of Edward Tulane, to determine the cause of his change and to find out its meaning of it applies objective approach. The result indicates that Edward Tulane's character is developing from an arrogant to caring rabbit china doll.
\end{abstract}

Keywords: character, character development, Edward Tulane, novel, Kate Dicamillo

\section{INTISARI}

Artikel ini meneliti novel yang berjudul The Miraculous Journey of Edward Tulane oleh Kate Dicamillo. Tujuan dari artikel ini adalah untuk menguraikan bagaimana perkembangan karakter Edward Tulane, menentukan sebab dari perkembangannya dan mencari makna dari perkembangan karakternya. Analisis dilakukan menggunakan pendekatan objektif. Hasil penelitian ini menunjukkan bahwa Edward Tulane berubah dari boneka kelinci porselen yang arogan menjadi boneka kelinci porselen yang peduli terhadap yang lainnya.

Kata Kunci: karakter, perkembangan karakter, Edward Tulane, novel, Kate Dicamillo 


\section{INTRODUCTION}

The novel chosen for this research is entitled The Miraculous Journey of Edward Tulane, written by Kate Dicamillo. This novel was released in 2006 and won the 2006 Boston Globe-Horn Book Award in fiction category. The novel tells about a china rabbit named Edward Tulane which is going through an interesting journey that changes its life. Edward Tulane is the most important character in this novel. That is why Edward Tulane's character development is worth to analyze.

The objectives of this research are to identify the development of the character ofEdward Tulane in Dicamillo's novel entitled The Miraculous Journey of Edward Tulane, to determine the cause of his character development, and to find out the meaning of his character changing.

The primary data of this research are taken from the novel, The Miraculous Journey of Edward Tulane by Kate Dicamillo. The data are the scenes, including the dialogues and narrations which involve Edward Tulane. To support the data, other books that are related to the research such as Abram's A Glosary of Literary Terms and Mirror and the Lamp, Griffith's Writing Essays About Literature, Guerin et al's A Handbook of Critical Approaches to Literature, internet sources, and other possible sources are also used. The data are collected through reading the work by focusing on Edward Tulane's thought and how the writer of the novel describes him. The method includes some steps in the analysis of the data. First, the data are identified, described and interpreted, and then inferences or conclusions are drawn from the interpreted data.

To the best of the writer's knowledge, there has not been any previous article which discusses about Edward Tulane's character development in Kate Dicamillo's The Miraculous Journey of Edward Tulane. However, there are some reviews and discussions about Edward Tulane's character development which are found on the internet. The first review is The Miraculous Journey of Edward Tulane by Kate Dicamillo: Rabbit Redux (Hearn). On his review, Hearn mentions Kate Dicamillo's works before The Miraculous Journey of Edward Tulane. Hearn also adds the summary of The Miraculous Journey of Edward Tulane on his review. The second review is The Miraculous Journey of Edward Tulane (Deigh). On the web, Deigh describes what Edward Tulane is like. Edward is spending his days facing the picture window. $\mathrm{He}$ prefers winter because when the sun sets early he can see his reflection in the glass. Deigh also adds that Dicamillo, the writer of the novel, paints Edward's circumstances with enough pathos and humor to render him charming, yet shows enough of his heartless self-importance to keep frombeing maudlin.

This paper elaborates the character development of Edward Tulane in Dicamillo's The Miraculous Journey of Edward Tulane, which means dealing with the intrinsic elements of the work. Therefore, Abram's objective approach is applied. Abrams in The Mirror and the Lamp states:

The objective orientation, which on principle regards the work of art in isolation from all these external points of reference, analyze it as a self sufficient entity constituted by its part in their internal relations and sets out to judge it solely by criteria intrinsic to it is own mode of being. (26)

In his book which is entitled $A$ Glossary of Literary Terms, Abram states:

Objective research deals with a work of literature as something which stands free from what is often called "extrinsic" relation to the poet, audience, or to the environing world. It describes the literary product as a self-sufficient object or integer, or as a world-in-itself, which is to be analyzed and judged by 'intrinsic' criteria such as complexity, coherence, equilibrium, integrity, and the interrelation of its component elements. (52)

1 http://en.wikipedia.org/wiki/The_Miraculous_Journey_of_Edward_Tulane 
This approach is suitable for the analysis, since the writer is analyzing the character development of the main character in Dicamillo's The Miraculous Journey of Edward Tulane.

\section{ANALYSIS \\ This part explains how Edward Tulane's cha- racter in Dicamillo's novel The Miraculous Journey of Edward Tulane is developed through the events experienced by Edward. Through those events, Edward meets some people who play important roles in Edward Tulane's character change. How the relation among the characters in an event can change Edward Tulane's character are shown. Furthermore, the causes of Edward Tulane's character change are also included on this part.}

\section{- Edward Tulane's bad character}

Edward Tulane is a rabbit china doll. He lives with the Tulane family which consists of Mr. Tulane, Mrs. Tulane, Abilene Tulane, and Pellegrina (Abilene's grandmother). Edward Tulane belongs to Abilene Tulane, the Tulane's only child and she is ten years old. Pellegrina gives Edward to Abilene as her seventh birthday present, and since that time, Abilene is always together with Edward. Abilene loves Edward so much and she treats him very well, even as if Edward is alive.

Unfortunately, Edward does not love Abilene the way Abilene loves him. What Edward cares is only about himself. Since Edward is made of real rabbit fur, of course beneath it all Edward is made entirely of china, he always adores himself. He always thinks that he is an exceptional specimen. He is tall, almost 3 feet or almost one meter, he also has blue eyes, so there's nothing about himself that he is not proud of. Maybe only one thing and that thing is his whiskers. He is not really sure where those whiskers came from. He has strong feeling that those whiskers are not rabbit whiskers. He keeps wondering to whom those whiskers belong to before, to what unsavory animal those whiskers belong to, but he decides to not think further about it because he does not like to have unpleasant thought. He is really an arrogant rabbit since he thinks that he is the only good one while the others are not. In addition, he likes his own reflection. In the book, Edward thought is depicted by the writer "And what a reflection it was! What an elegant figure he cut! Edward never ceased to be amazed at his own fineness." (Dicamillo 6)

An event occurs when the maid of Tulane's household finds Edward and she intended to clean Edward up, in order to impress her employers with her diligence. The maid vacuums Edward Tulane, and that vacuum cleaner is sucking each of Edward's long ears up. The maid cleans Edward up in a brutal way. After she has done vacuuming Edward, she places Edward on the shelf in inhuman position; Edward's nose is touching his knees and he is just waiting there. Until Abilene is coming back from school and finds him not in his place before. Abilene hugs himbecause she thought that he was missing. Abilene says to Edward that she loves him and she does not want Edward to be away from her, but Edward is only relieved because Abilene found him. No, he does not feel the love which Abilene feels. The writer describes Edward feeling at that moment:

The rabbit, too, was experiencing a great emotion. But it was not love. it was annoyance that he had been so mightily inconvenienced, that he had been handled by the maid as cavalierly as an inanimate object — a serving bowl, say, or a teapot. (Dicamillo 17-18)

From this event it proves more that Edward does not like to be treated as an inanimate object. He wants everybody treats him like human being in general. Through this event, it also can be concluded that Edward is only care for himself. He does not care about other people feeling. He does not care how Abilene is afraid to lose him. When Abilene is found him, he only knows that he will not be sitting with that position anymore and Abilene will put him back to Edward's original place.

In short, Edward is a proud, arrogant, selfish rabbit china doll when he is still with Abilene. Until one day, when Edward is going with Tulane's family voyage to England, he falls to floor ground of the 
sea. This is the beginning of Edward Tulane's character change. After this, Edward will meet several people who help him to improve his bad character. This incident is the first cause of Edward Tulane's character change.

\section{- The beginning of Edward Tulane's character change}

When Edward Tulane is going overboard, he hears Abilene is shouting out his name, "Edwaaarrd, come back." In that situation, Edward thinks that Abilene is ridiculous because she wants him to come back yet she knows that Edward cannot move. Even when Abilene is worrying about him since he is in danger, Edward still does not understand that Abilene loves him so much. In that kind of situation, he is still able to think that Abilene is ridiculous. Edward is indeed a careless china rabbit doll.

Edward is trapped on the ocean floor for months. During his days in the ocean floor, Edward, who was taking Abilene for granted before, is asking for Abilene's help for the first time. That is the thing that Edward would never do before because Abilene has already done everything for Edward without Edward asks for it.

He told himself that certainly Abilene would comeand find him. This, Edward thought, is much like waiting for Abilene to come home from school. I will pretend that I am in the dining room of the house on Egypt Street, waiting for the little hand to move to the three and the big hand to land on twelve. If only I had my watch, then I would know for sure. But it doesn't matter; she will be here soon, very soon. (Dicamillo 53)

This is the first cause of Edward Tulane's character development. Because if this is never happening, then Edward Tulane would be constant as an arrogant and self-centered rabbit china doll. He will keep taking for granted those people who love him and he will never appreciate them. He will keep thinking that the one that matters is only himself. This incident becomes a strong root for Edward's character change, and then it is supported by other events which force Edward to realize his faults.

It is Lawrence who finds Edward in the sea after two hundred and ninety seven days since he is being apart with Abilene. After Edward is lifted by sea storm, Lawrence, a fisherman, accidentally catches him with his fishing net. He decides to take Edward home and give him to Nellie, his wife. Just like what Lawrence has expected, Nellie is very happy to get a china rabbit from his husband and direct from the sea. Right after Nellie sees Edward, she praises him immediately, "Have you ever in your life seen anything so fine?'. and Edward feels Nellie is a very discerning woman, of course because of that compliment. Yes, Edward is still self-centered, proud and arrogant. Since Lawrence and Nellie do not know Edward's name is Edward Tulane, so they call him Susanna, a girlname.

After meeting Lawrence and Nellie, Edward's character starts to change slowly. When Nellie is dressing him with a dress and gives him a girl name, he accepts it although at first he grumbles since he is a boy china rabbit. It seems like being on the ocean floor teaches him how to be grateful.

He was horrified at first. He was, after all, a boy rabbit. He did not want to be dressed as a girl. And the outfits, even the special-occasion dress, were so simple, so plain. They lacked the elegance and artistry of his real clothes. But then Edward remembered lying on the ocean floor, the muck in his face, the stars so far away, and he said to himself, what difference does it make really? Wearing a dress won't hurt me. (Dicamillo 69-70)

If this event happens before Edward is falling to the ocean floor, he would definitely hate Nellie for dressing him like a girl rabbit. Since he has experienced how it feels like being on the ocean floor, dressing like a girl rabbit is better than have to experience falling into the sea again.

Another event which proves that Edward character is starting to change is when Nellie tells Edward about her children and her last child named Raymond died because of pneumonia. Nellie tells 
him how heartbreaking it was to see Raymond drowned himself and she could do nothing and only sees her loved one is dying before her eyes, and what Edward does is listening to her. It is something Edward never did when he was with Abilene, when he was with the Tulane family. Edward is also taken aback with himself.

And Edward was surprised to discover that he was listening. Before, when Abilene talked to him, everything had seemed so boring, so pointless. But now, the stories Nellie told struck him as the most important thing in the world and he listened as if his life depended on what she said. It made him wonder if some of the muck from the ocean floor had gotten inside his china head and damaged him somehow. (Dicamillo 71)

Edward begins to open his heart little by little since he meets Lawrence and Nellie, and this is also caused by ocean floor incident. Edward starts to care about other people, not only care about himself.

It is true that Edward has been developing affection towards other people, but his poor character shows up again when Lawrence and Nellie's daughter, whose name is Lolly, is coming home. The writer of the novel is describing Edward's feeling that he is already formed a deep and abiding hatred for Lolly. That can be understood since Lolly is a woman who speaks too loud and she wears too much lipstick. Still, hating someone when you do not even know that person is not a good deed.

In the end, Edward has got to be separated with Lawrence and Nellie because of Lolly. Lolly throws Edward away to the dumpster. He stays there with orange peels, coffee grounds, rancid bacon, and rubber tires. During Edward's days in the dumpster, he is furious with Lolly who throws him away to that horrible place. He wants to find Lolly and exact revenge on her, but Edward is there at the dumpster for too long, until he gives up on revenge towards Lolly. Edward is in despair at that time and he begins to reflect on himself.
Being apart from the people who love him makes Edward's arrogance is lessen little by little. He starts to know his mistakes and also realizes those are the ones which bring him to that situation. He still has those poor characters, but Edward is better than before. Since Edward meets Lucy and Bull, his character is getting better.

Lucy, Bull's dog, finds Edward on Edward'sone-hundred-and-eightieth-day at the dumpster. And then Lucy brings Edward to Bull with Lucy's slobbery mouth. Edward knows that it is dirty, but he is happy. He is happy since he can escape from the dumpster. There is no way Edward will like being dragged by a shabby dog's mouth if he is still with Abilene.

Bull is a hobo, he is homeless and he is having a journey without destination. Lucy always accompanies him, and now since Lucy brings Edward, Edward will also accompany Bull's journey. Since Bull does not know Edward's name is Edward Tulane, he calls Edward Malone.

Whenever Bull and Lucy fall asleep, Edward will look at the stars and saying the names of the constellation and also the names of the people who loved him. He always starts with Abilene and then Nellie and Lawrence, Bull and Lucy are also mentioned. And when he finishes mentioning those names, he will start again from Abilene until Bull and Lucy. Being separated from the ones who love him makes him reflect on himself and learn what love is and how to love.

Accompanying Bull and Lucy in their journey, Edward is still often being referred as a doll by other people who see them and he still does not like it. He is still angry about it but because Bull never gets angry and he always ignores those who mock him, Edward learns patience from Bull and just let it slide. Eventually the hobos are getting used to Edward's presence and Edward's existence is spreading. They become so glad to see Edward and everybody is recognizing him as Malone. Edward, of course, feels the pleasure he is got from being recognized and being known. Since he was with Nellie, he has this 
new and strange ability and that is to listen and concentrate to the stories of another. That ability becomes invaluable around the hobo's campfire.

Edward has been with Bull and Lucy almost for seven years and he is happy to be with them. Although they do not have any destination, Edward does not mind at all. Until that night when Edward, Bull and Lucy are sleeping in an empty freight car, the trouble comes. There is a man who is flashing them on with a flashlight. That man is intended to dismiss them from that freight car because that freight car is not a motel, he said. Lucy starts to bark at him, then that man gives a swift kick to Lucy's side which makes her yelp in surprise. That is the very first time Edward wishes he could move himself. That is also the first time he regrets that in fact he is only a china doll.

And he had never regretted this more deeply than he did that night when he and Bull and Lucy were discovered in the empty railcar. Edward wanted to be able to defend Lucy, but he could do nothing. He could only lie there and wait. (Dicamillo 109)

In the end, Edward is being kicked from the railcar by that man. Edward only hears Lucy's anguished howl and he falls down to a dirty hill on his back, staring up at the night sky. At that time he says the names, Bull and Lucy. He wonders how many times he has to leave without getting the chance to say goodbye. He is ached and he wishes that he could cry.

\section{- Edward Tulane Starts Losing Hope}

After that incident, Edward is found by an old woman. That old woman then uses Edward for scaring the crows off. That old woman calls Edward as Clyde, which annoys Edward so much. He is wondering when the world will call him by the right name. The old woman leaves him out there to scare the crows off while she is going to her house. He is alone there. Edward stares at the stars but he still feels so alone. That is the first time for Edward not finding any joy staring at the stars.
Edward hung by his velvet ears and looked up at the night sky. He saw the stars. But for the first time in his life, he looked at them and felt no comfort. Instead, he felt mocked. You are down there alone, the stars seemed to say to him. And we are up here, in our constellations, together. I have been loved, Edward told the stars. (Dicamillo 119)

Edward is tired for always parting with those who he has opened his heart for. He even never could say goodbye to them.

Then Edward meets Bryce and Bryce brings him to Sarah Ruth, his little sister who has been sick all this time. Bryce is the old woman's laborer. He sees Edward is hung upon a pole, and immediately says that he will back to get him. Then Bryce is back when the day is already dark, but Edward thinks that it is too late, he is just a hollow rabbit, while Bryce is unleashing the wire tied around Edward's wrist. Edward thinks it is too late because he is just a doll made of china, while Bryce is pulling the nails out of Edward's ears. This event shows Edward's despair, where Edward does not care anymore if he has to be saved or not. The incidents which are happened before makes him tired for wishing to be saved, but when Bryce is finally succeeded to release Edward and put him in his arms, Edward feels like finding a new hope. He is relieved and it is followed by one of joy feeling. "Perhaps, he thought, it is not too late, after all, for me to be saved." (Dicamillo 126)

\section{- Edward Regains His Hope}

Next, Bryce brings Edward to his house, to meet his diseased sister, Sarah Ruth. This time is different than before because Edward is able to love Sarah Ruth in no time.

By the time Bryce arrived at his house, he immediately wakes Sarah Ruth up to give her the china doll. Sarah Ruth finally wakes up and sits up in her bed. She starts to cough and cough, and Bryce puts his hand on her back and let her cough until the cough stops. When she is better, Bryce gives Edward to her. As expected, Sarah Ruth is very 
happy to get it. Sarah Ruth once ever had a china doll, but his father stepped on that until it is broken. So Bryce brings Edward as the replacement.

Sarah Ruth is very happy for having a new doll, and she treats that china doll as a baby. She puts Edward in her arms and rocks him back and forth while staring down at him and smile. Edward feels something new and feels the pleasure he never felt before.

Never in his life had Edward been cradled like a baby. Abilene had not done it. Nor had Nellie and most certainly Bull had not. It was singular sensation to be held so gently and yet so fiercely, to be stared down at with so much love. Edward felt the whole of his china body flood with warmth. (Dicamillo 133-135)

Edward feels the love right after meeting Sarah Ruth, and it never happened before. When he met Nellie and Lawrence, Lucy and Bull, it took some times to feel the love for those people, and it is different for Sarah Ruth. He easily opens his heart for her.

Sarah Ruth decides to call Edward as Jangles. Bryce thinks that is a good idea, and Edward Tulane says nothing about it which means that he is agreed as well. As what has been mentioned before, Edward was complaining when the world will call him by the right name, but it is different in Sarah Ruth case. Edward does not mind at all. It is okay for Sarah Ruth to call him anything. He does not have any complaint even in the beginning Edward arrives at Sarah Ruth's place. It proves that Edward loves Sarah Ruth immediately. It is something Edward never does before.

There is this event, whenever Sarah Ruth is coughing then she will squeezes Edward so tight like she will break him, and in the meantime she is also sucking Edward's ears. This is an event which Edward will definitely hate if he has not changed, just like before when he was with Abilene, but right now he is okay with it.

Sometimes, when a coughing fit was particularly bad, she squeezed Edward so tight that he was afraid he would crack in two. Also, in between coughing fits, she took to sucking on one or the other Edward's ears. Normally, Edward would have found intrusive, clingy behavior of this sort very annoying, but there was something about Sarah Ruth. He wanted to take care of her. He wanted to take care of her. He wanted to protect her. He wanted to do more for her. (Dicamillo 141)

This event is proving that, indeed, Edward is giving all his love to Sarah Ruth, even right from the beginning of their meeting. Edward's character has a very significant improvement since he met Sarah Ruth.

Months passed, Sarah Ruth's condition is getting worse. In the fifth month, Sarah Ruth refuses to eat. Even in the sixth month, she starts to cough up blood. Breathing becomes a hard thing to do for her. Deep inside, Edward also reminds Sarah Ruth to breathe, even though Sarah Ruth will never know it. Unfortunately, on a bright morning in September, Sarah Ruth stops breathing. Sarah Ruth is no longer holding Edward. Edward is facing down the floor, his arms are over his head, and he listens as Bryce weeps. Bryce then brings Edward to Memphis.

After Edward is separated with Abilene, Edward's meeting with these people is the second cause of Edward Tulane's character change. The people who Edward has met have their own condition which is considered that they are not as lucky as Abilene. Nellie and Lawrence who are only live by themselves. Their children are rarely coming home, and their last child is dead because of pneumonia. Meanwhile, Bull and his dog have no permanent place to stay. They are always wandering here and there. They are having a journey without a clear destination. Furthermore, Bryce and Sarah Ruth are categorized as unlucky kids. Bryce has to work to make a living for him and for his diseased little sister. Their father does not take care of them. Their father let them live alone in a small and crooked house, a house which more looks like a chicken coop. In the end, Sarah Ruth must die because of her disease. 
Because of Edward meets these people who are considered as unlucky people, it arouses his sympathy. Edward wants to take good care of them and Edward wants to protect them. Edward learns what love is from them. Because of Nellie, Edward knows how to listen and appreciate what other people are talking. From Bull, Edward learns how to not worry about what negative people say about him. Edward learns to hold his anger and just let those who annoy him slide. From Sarah Ruth, Edward learns to sacrifice for the people he loves. There are so many lessons Edward got from them. They are the factors why Edward's character is changing into a better character.

\section{- The Climax of Edward Tulane's Character Change}

In Memphis, Bryce makes Edward as a dancing rabbit. Bryce does that to make a living, to make them survive. Edward is okay with it, he does not complain at all, but the ache from losing Sarah Ruth still remains. He feels like nothing mattered, and nothing would ever matter again. Edward only wants Sarah Ruth to hold him, as usual. Edward wants to dance for her in order for her to forget the pain she feels. Edward is sad for the fact that he is indeed dancing, but it is not for Sarah Ruth

An incident occurs when Bryce is hungry and he goes to a restaurant to eat there. Unfortunately, Bryce cannot pay for what he has eaten. The owner of the restaurant is getting angry and throws Edward until Edward's head is hitting the edge of a table. A loud crack is heard. Bryce is screaming because of that incident, and for a moment, Edward's world is going black.

Bryce brings Edward to a doll mender whose name is Lucius Clark. Lucius Clark tells Edward that the incident before has made his head broken into twenty-one pieces. He also adds that if it was not him, the other doll menders would not be able to put him together into one as before.

The doll mender says that Bryce came to him while wept and he wanted Lucius to fix Edward. But Lucius, of course, asked for fee to do that kind of thing. Lucius did not so sure ifBryce can pay him so he gave Bryce two choices; first is Bryce brings him to another place, and second is Lucius will fix Edward but after that Edward should be his, not Bryce's anymore. Bryce chose the second choice. Then the doll mender sells Edward in his doll shop.

One day, the doll mender puts Milady, a onehundred-years-old doll, next to Edward. Milady is a positive doll. She tells Edward that she had been in many places, since he is a one-hundred-yearsold doll, and she also adds to Edward that in those different places, she always learned something new. She becomes a different doll in each place, too. So, Milady is looking forward to her next owner. She wonders who it will be, but Edward gives respond that he does not care if anyone comes for him. Then Milady says that it is dreadful for not having expectancy. She tells Edward that he must wonder who will love you, and whom you will love next, but Edward says, "I'm done with loving. It's too painful." Afterward, the old lady says, "You disappoint me. You disappoint me greatly. If you have no intention of loving or being loved, then the whole journey is pointless." (Dicamillo 199). Milady suggest him to jump out of the shelfand break himself into a million pieces, life has no use if you do not have any intention to love and to be loved and Edward would do that if only he could move his body.

Milady words "You disappoint me" remind Edward about Pellegrina; about the princess and the warthog, about listening and love, and about spells and curse. Then Edward wonders if it is possible if there is somebody who waits to love him and if there is somebody whom he would love again, but he does not want to have a high hope. So he tells himself that that kind of thing is not possible. In the next morning, a lovely girl purchases Milady and there Edward is being alone again. Before Milady goes to her new owner, she is still able to tell Edward to open his heart. She says that someone will come to him, but first, Edward should let his heart opened. Edward tries so hard not to believe what the old doll has said, but it is too late, Edward begins to 
hope again. From that old doll words, Edward finds his courage to open his heart again.

After years passed, There is a little a girl, about five years old, enters the shop while her mother is busy closing her umbrella. That little girl looks up to the shelf and she takes Edward to her arms. Edward is familiar with this kind of feeling. It is like he is being carried in Sarah Ruth's arms. The doll mender warns the mother that her daughter is carrying his fragile and expensive doll. Then the mother tells her daughter that she has promised that they come to the doll shop only for looking and they will not buy anything, but her daughter wants that doll, that rabbit china doll. When the mother looks down to the doll, she says, "Edward?" and Edward realizes, it is Abilene and his pocket watch is hanging on her neck. Edward answers in his heart, "Yes. Yes. Yes. It is me."

The separation with the people Edward loves like Nellie and Lawrence, Lucy and Bull, Bryce and Sarah Ruth is also the cause of Edward's character change. Because Edward is experiencing these separations, then he realizes how happy he was when he was with those people. If Edward is separated only from Abilene, then when he meets new people and that new people are taking good care of him for the rest of their life, Edward will not learn how painful it is to be separated with the people who love him and people who he loves for many times.

\section{CONCLUSION}

Edward Tulane, who was an arrogant, selfish, self-centered and proud, has changed into a loving and caring rabbit china doll. If Edward is not separated from Abilene, and he is also not experiencing meeting with new people who he is parted with without ever saying goodbye, probably Edward would not change into a better rabbit. Edward would perhaps still a self-centered doll. Now, he appreciates those who love him, does not take them for granted, and gives the amount of love as much as they have given him.

\section{REFERENCES}

Abrams, M.H. A Glossary of Literary Terms. Boston: Earl McPeek, 1999.

-. The Mirror and the Lamp: Romantic Theory and Critical Tradition. London: Oxford University Press, 1971.

Deigh, Bonnie. "The Miraculous Journey of Edward Tulane.” Foreword Reviews. 18 Aug. 2009. Web. 30 Jan. 2015. <https://www. forewordreviews.com/reviews/the-miraculousjourney-of-edward-tulane/>.

Dicamillo, Kate. A Miraculous Journey of Edward Tulane. Somerville: Candlewick Press, 2006.

Griffith, Kelly. Writing Essays About Literature: A Guide and Style Sheet. Boston: Michael Rosenberg, 2011.

Guerin, Wilfred L, et al. A Handbook of Critical Approaches to Literature. New York: Oxford University Press, 2005.

Hearn, Michael Patrick. "The Miraculous Journey of Edward Tulane by Kate Dicamillo: Rabbit Redux." The New York Times. 14 May. 2006. Web. 30 March. 2015. http://www.nytimes. com/2006/05/14/books/review/ 14hearn.html?_r=0

"The Miraculous Journey of Edward Tulane." Wikipedia. Web. 6 June. 2014. <http:// en.wikipedia.org/wiki/The_Miraculous_ Journey_of_Edward_Tulane.> 